\title{
Control of movement of heat front during oil reservoir with thermal treatment
}

\author{
Bagir Ali BAGIROV ${ }^{1, *}$, \\ Agharza Mesud HAJIYEV2,** \\ ${ }^{1}$ SOCAR, OilGas Scientific Research Project Institute, Baku, Republic of Azerbaijan \\ ${ }^{2}$ Azerbaijan State Oil \& Industrial University, Baku, Republic of Azerbaijan
}

\begin{abstract}
Relevance. For efficiency of oil field development, Enhanced Oil Recovery (EOR) methods are used. These methods can be classified into physical-chemical, thermal, microbiological, nuclear, etc. Among these treatments, the thermal method has a special place. It is related to the fact, that these methods are applied to the formations with scavenger (tight) oil, where ultimate oil recovery factor otherwise cannot exceed 0.2-0.3. Thermal methods are aimed to reduce the viscosity of the oil, thus increasing its mobility in the reservoir. The method is based on pumping the driving substance (steam or hot water) into the reservoir, and also on burning the oil in the reservoir (in-situ combustion).

Purposes and objectives of the study. The efficiency of the thermal treatment largely depends on geological and physical conditions of the oil reservoir - its depth, physical and chemical characteristics of the fluids, reservoir type, oil, gas and water saturation.

The substance to be heated in the reservoir is oil. However, part of thermal energy heats water and the rock as well. Therefore, it is very important to study the reservoir before the start of thermal treatment. Geologically heterogeneous layers especially require detailed study.

The thermal methods have been tested on the reservoirs, occurring at different depth. However, the efficiency of thermal treatment decreases with depth. The reason for that is the loss of the heat on its way in the borehole, from one hand, and higher temperature of the formation itself, on the other. That is why, the application of the thermal methods on the deeper horizons are limited.

Results and recommendation. Apparently, the successful application of thermal treatment of the reservoirs requires the systematic monitoring of the development process, which allows to correct the treatment process in a timely manner. Getting the information about formation current physical characteristics, making temperature measurements are challenging and expensive processes. The processing of the information also takes time. All of this can have negative effect on ultimate recovery factor. Usually, construction of isotherm maps is recommended for thermal treatment monitoring. However, these maps not always indicate the direction of the movement of the injected heat. Thus, the effective method of controlling and monitoring of the thermal treatment is very relevant task of the reservoir geology.
\end{abstract}

Keywords: reservoir, oil recovery, thermal treatment, temperature, exposure to steam, in-situ combustion, water mineralization.

I ntroduction

For efficiency of oil field development, Enhanced Oil Recovery (EOR) methods are used. These methods can be classified into physical-chemical, thermal, microbiological, nuclear, etc. [1-3].

Among these treatments, the thermal method has a special place. It is related to the fact, that these methods are applied to the formations with scavenger (tight) oil, where ultimate oil recovery factor otherwise cannot exceed 0.2-0.3 [4]. Thermal methods are aimed to reduce the viscosity of the oil, thus increasing its mobility in the reservoir. The method is based on pumping the driving substance (steam or hot water) into the reservoir, and also on burning the oil in the reservoir (in-situ combustion).

The efficiency of the thermal treatment largely depends on geological and physical conditions of the oil reservoir - its depth, physical and chemical characteristics of the fluids, reservoir type, oil, gas and water saturation.

The substance to be heated in the reservoir is oil. However, part of thermal energy heats water and the rock as well. Therefore, it is very important to study the reservoir before the start of thermal treatment. Geologically heterogeneous layers especially require detailed study.

The thermal methods have been tested on the reservoirs, occurring at different depth. However, the efficiency of thermal treatment decreases with depth. The reason for that is the loss of the heat on its way in the borehole, from one hand, and higher temperature of the formation itself, on the other. That is why, the application of the thermal methods on the deeper horizons are limited.

Apparently, the successful application of thermal treatment of the reservoirs requires the systematic monitoring of the development process, which allows correcting the treatment process in a timely manner. Getting the information about formation current physical characteristics, making temperature measurements are challenging and expensive processes. The processing of information also takes time. All this can have negative effect on ultimate recovery factor. Usually, construction of isotherm maps is recommended for thermal treatment monitoring. However, these maps not always indicate the direction of the movement of the injected heat. Thus, the effective method of controlling and monitoring of the thermal treatment is very relevant task of the reservoir geology.

Suggested method

The method is based on the fact, that injected heat transfer agent will increase the temperature and mobility of fluids, but will also change the ion and salt composition of the formation water. The heat transfer agent can be steam, hot water, as well as the products of combustion of oil in the reservoir [5-7]. One has to pay attention to the fact that the water flow in the reservoir is faster than the spreading of the heat in the rock matrix or in the saturated fluids. Therefore, the change in water chemistry is meaningful indicator, which allows finding areas and zones of the field affected by thermal treatment. The behavior of chemical components of the solution depends on the method of treatment. Injected steam will decrease the salinity, or mineralization, since injected substance is basically distilled water. In-situ combustion decreases the viscosity of oil, but also increases the temperature

\footnotetext{
$\triangle$ b.bagirov.36@mail.ru

"agarza.haciyev@gmail.com
} 


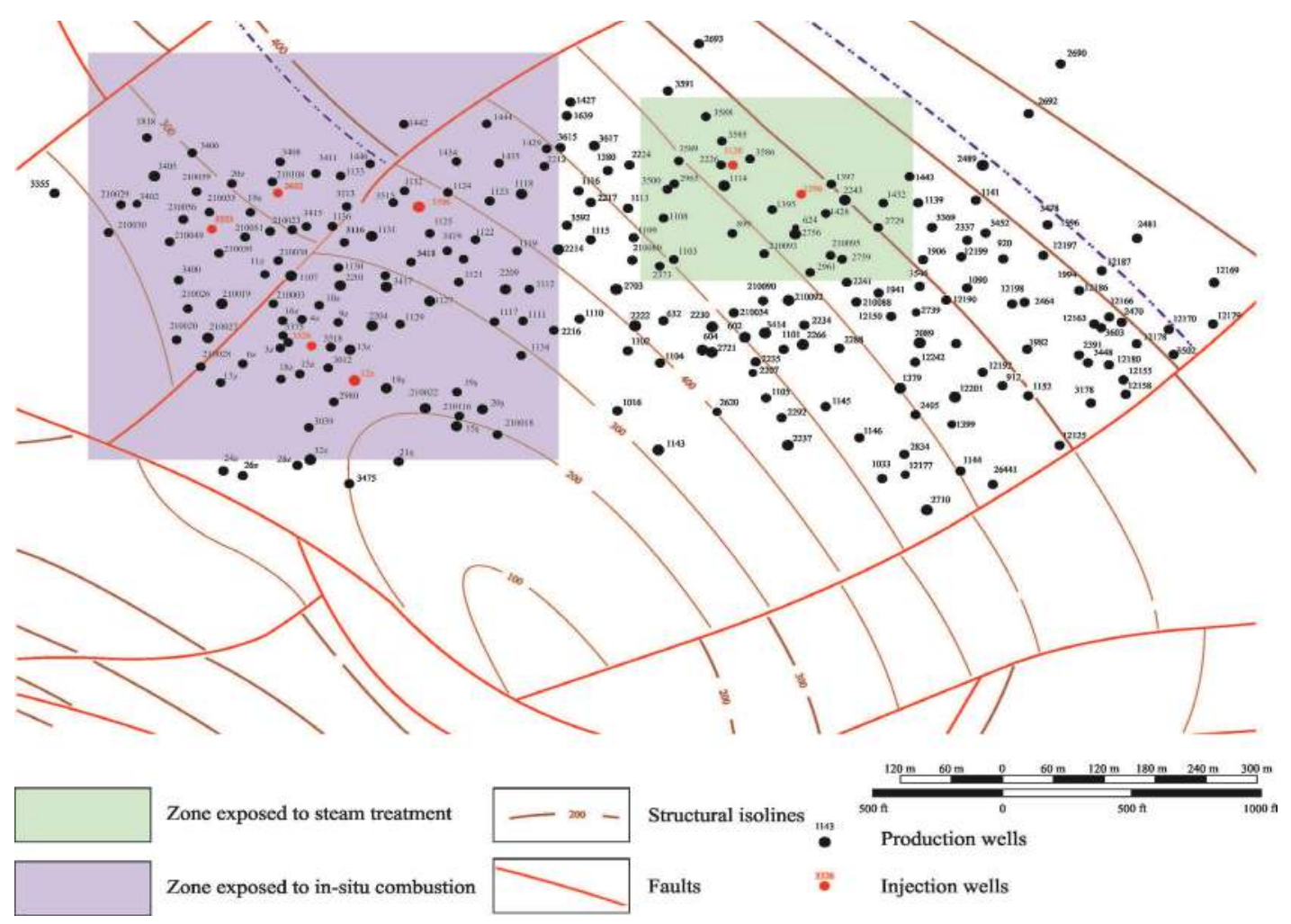

Figure 1. Thermal treatment zones in Balakhany-Sabunchi-Ramany field.

Рисунок 1. Зоны тепловой обработки пласта в месторождении Балаханы-Сабунчи-Раманы.

of formation water, which increases its reactivity and solubility of components of the rock matrix. Therefore, water produced with the oil will have higher mineralization and, as a rule, the content of $\mathrm{Na}+\mathrm{K}$ and $\mathrm{Cl}$ ions will increase.

As for hot water injection (which has not been applied in the Azerbaijan oil fields), it is reasonable to suppose that the water chemistry will change according to the chemical composition of the dissolved salts in the injected water [8].

Case studies

Below are the specific examples of realization of the suggested method.

Exposure to steam. This method was successfully used in the oil reservoir horizons II $\mathrm{KS}_{\mathrm{u}}$ of Balakhani-Sabunchi-Ramany field (Khorasan Zone). The target is represented by frequent and uniform alternation of thin (35-45 m thick) interbeds of argillaceous and sandy rocks. Average porosity is $25 \%$ and average permeability is $0.215 \mathrm{mkm}^{2}(215 \mathrm{mDa})$. The area covered by thermal treatment is not complicated by faults and has $18-25^{\circ}$ dip angles.

In place conditions the density of oil is $0.920-0.935 \mathrm{gcc}(19.8-22.3 \mathrm{API})$, while the viscosity is $75-110 \mathrm{mPa} \times \mathrm{s}$. Although the horizon has been developed since 1924, at the beginning of treatment the current oil recovery coefficient was only 0.19 . Average daily well rate were between $0.6-3.2 \mathrm{t}\left(4-22 \mathrm{bbl}\right.$ ) oil and $0.1-8.0 \mathrm{~m}^{3}$ water. WCO was $55-65 \%$, while formation pressure of the site fluctuated from 0.07 to $1.25 \mathrm{MPa}$. To enhance filtration properties of oil in porous environment of the studied zone steam injection was first implemented in well No. 1396 (1969), and then in well No. 1128 (1970). The temperature of working agent (steam) at the wellhead was $200-220^{\circ} \mathrm{C}$ at $3.0 \mathrm{MPa}$ injection pressure (Fig. 1).

It must be noted that the steam injection operations create three specific phase zones - steam drive zone, hot condensate zone and unswept zone [9]. Each of indicated zones affects each other. By compensating each other these zones indicate the nature and direction of heat front.

The work describes the study results of impact of temperature on physical and chemical features of the oil and reservoir water in test wells (No. 2220, 2281, 2547, 2238, 2227). It was established that the test wells exhibit regular decrease in viscosity and density of produced oil with rising temperature. However, the wells where no changes in the temperature of formation were observed (2236), there was some improvement in oil mobility. This suggested that the thermal flow affected wider area. At that, the studies indicated the considerable changes in reservoir water even in the wells where formation temperature did not change. The salinity of this water reduced from $2.5-3.1$ to $0.5-2.8^{\circ} \mathrm{Be}$ as a result of mixture with steam condensate (Table 1).

Comparison of physical-chemical characteristics of formation water has shown that its properties change as a result of advanced penetration of steam condensate (which is actually distilled water) via more permeable sub-layers. Such situation was observed even in wells (No. 1397, 1934), where other geological-engineering characteristics remained stable (Fig. 2).

In the course of controlled steam treatment, it was found that monitoring of hydrochemical conditions within formations in dynamics allows identifying directions of the heat flow in formations, and this can be used for control of used treatment method $[4,10]$.

In-situ combustion. This method is based on the capability of hydrocarbons to release heat as a result of oxidizing reactions. Heat generation directly within formation is main advantage and characteristic feature of this method. In-situ combustion works efficiently in clastic reservoirs. Disadvantage of this method is that more than $25 \%$ of oil in the reservoir is burned as a fuel, whilst final oil recovery can be increased to $20 \%$ when using this method $[8,11-15]$. 
Table 1. Physical-chemical characteristics of formation water of horizon II KS $\mathrm{u}_{\mathrm{u}}$ Balakhany-Sabunchi-Ramany field.

Таблица 1. Таблица 1. Физико-химические показатели пластовой воды на залежах горизонта II КС в месторождении Балаханы-Сабунчи-Раманы.

\begin{tabular}{|c|c|c|c|c|c|c|c|c|c|c|c|c|}
\hline \multirow{3}{*}{ Well } & \multicolumn{6}{|c|}{ Before the treatment } & \multicolumn{6}{|c|}{ After the treatment } \\
\hline & \multirow[b]{2}{*}{${ }^{\circ} \mathrm{Be}$} & \multicolumn{5}{|c|}{ Equivalent values, equiv. } & \multirow[b]{2}{*}{${ }^{\circ} \mathrm{Be}$} & \multicolumn{5}{|c|}{ Equivalent values, equiv. } \\
\hline & & $\mathrm{Cl}$ & $\mathrm{HCO}_{3}$ & $\mathrm{Ca}+\mathrm{Mg}$ & $\mathrm{Na}+\mathrm{K}$ & $\Sigma_{a+k}$ & & $\mathrm{Cl}$ & $\mathrm{HCO}_{3}$ & $\mathrm{Ca}+\mathrm{Mg}$ & $\mathrm{Na}+\mathrm{K}$ & $\Sigma_{a+k}$ \\
\hline 2220 & 2.9 & 0.0311 & 0.0085 & 0.0014 & 0.0802 & 0.1212 & 0.5 & 0.019 & 0.0021 & 0.0013 & 0.0032 & 0.0261 \\
\hline 2281 & 2.9 & 0.0324 & 0.009 & 0.0017 & 0.0838 & 0.1269 & 2.8 & 0.0313 & 0.0091 & 0.002 & 0.0389 & 0.0818 \\
\hline 1431 & 3.1 & 0.0335 & 0.009 & 0.0015 & 0.0862 & 0.1302 & 0.7 & 0.021 & 0.0034 & 0.0009 & 0.0057 & 0.0315 \\
\hline 1397 & 3.0 & 0.0322 & 0.0093 & 0.0016 & 0.084 & 0.1271 & 2.6 & 0.0283 & 0.0091 & 0.0013 & 0.0156 & 0.0758 \\
\hline 1432 & 2.8 & 0.025 & 0.0112 & 0.0012 & 0.0733 & 0.1107 & 2.7 & 0.0256 & 0.0109 & 0.0014 & 0.0356 & 0.054 \\
\hline 2547 & 2.5 & 0.0239 & 0.0081 & 0.0019 & 0.065 & 0.0989 & 1.7 & 0.0156 & 0.0077 & 0.0011 & 0.0229 & 0.0478 \\
\hline 2238 & 2.7 & 0.0256 & 0.0104 & 0.001 & 0.073 & 0.11 & 2.5 & 0.0244 & 0.0101 & 0.001 & 0.0339 & 0.0699 \\
\hline 1934 & 3.1 & 0.0341 & 0.009 & 0.0015 & 0.0873 & 0.1319 & 2.8 & 0.0291 & 0.0098 & 0.0014 & 0.0383 & 0.0791 \\
\hline 2729 & 2.7 & 0.0246 & 0.0108 & 0.0011 & 0.0718 & 0.1083 & 2.7 & 0.0261 & 0.01 & 0.0014 & 0.0153 & 0.0533 \\
\hline 2248 & 2.9 & 0.0282 & 0.01 & 0.0013 & 0.0776 & 0.1171 & 2.8 & 0.0277 & 0.0106 & 0.0013 & 0.0175 & 0.0576 \\
\hline 2236 & 2.5 & 0.0232 & 0.009 & 0.0015 & 0.0655 & 0.0992 & 1.7 & 0.0124 & 0.0069 & 0.0011 & 0.0188 & 0.0397 \\
\hline
\end{tabular}

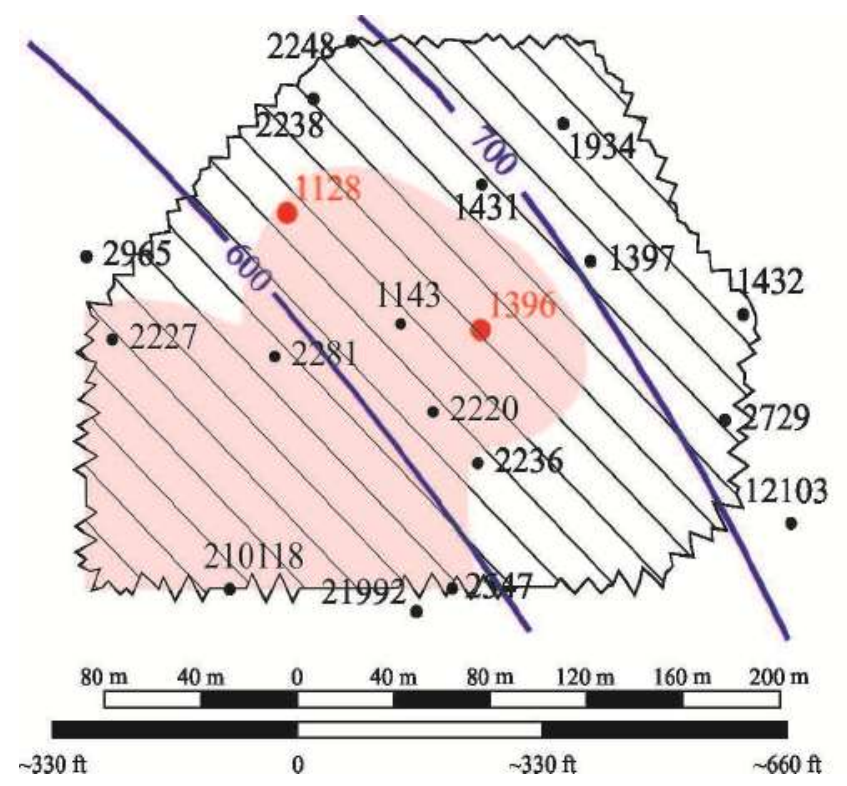

\begin{tabular}{ll}
\hline 1396 & Injection wells \\
$\qquad 2965$ & Test wells \\
\hline$-700-$ & Isolines \\
& $\begin{array}{l}\text { Zone of temperature } \\
\text { change }\end{array}$ \\
\hline & $\begin{array}{l}\text { Zone of water } \\
\text { mineralization change }\end{array}$
\end{tabular}

Figure 2. Map of heat distribution as a result of steam treatment in Khorasany area of Balakhany-Sabunchi-Ramany field.

Рисунок 2. Карта распределения тепла в результате паровоздействия в месторождении Балаханы-Сабунчи-Раманы (площадь Хорасаны).

Let us note that as a result of process of combustion in the reservoir, ion-salt composition of formation water from the treated wells has changed. We registered this effect in wells of the Balakhany-Sabunchi-Ramany and Pirallakhi fields.

1. Horizon PKu of the Balakhany-Sabunchi-Ramany field (Khorasany area). Here PK suite, unlike other areas of the field is characterized by low oil recovery factors $(<0.30)$, which is mainly related to high viscosity of oil $(>50 \mathrm{mPa} \cdot \mathrm{s})$. Accordingly, in 1973, people began to apply thermal treatment methods, in-situ combustion, in particular.

Summary of geological-engineering characteristics of target is the following.

Development of PKu began in 1919. Numerous wells have been drilled during the whole period of development, however, most wells were soon returned to the overlying formations due to low rates. The process of in-situ combustion was applied in wells No. 3326, 3323, 12z, 3396, 2632. More than 40 producers undergone treatment (Fig. 3).

Treatment continued up to 1995; during the whole period more than 600 thousand $\mathrm{m}^{3}$ of water and over $200 \mathrm{million}^{3}$ of compressed air have been injected into reservoir. As a result, about 230 thousand tons ( $1.5 \mathrm{~mm}$ bbl) of incremental oil was produced owing to its improved mobility at the expense of reduction of viscosity. Treatment was carried out under systematic monitoring and control. It should be noted that while temperature changes in the wells happened in different level, in most of them (particularly in wells 3375, 3z and 3518), physical-chemical characteristics of formation water changed significantly (Table 2, Fig. 4).

Period of thermal stimulation is shown in grey color.

It can be seen from the presented data that in the process of in-situ combustion in horizon $\mathrm{PK}_{\mathrm{u}}$ at the Khorasany area, hydrochemical parameters of formation experience various changes. In all cases increase of values of $\mathrm{Na}+\mathrm{K}$ и $\mathrm{Cl}$ ions is clearly seen, which allowed identifying zones of heat flow effect across the area. 


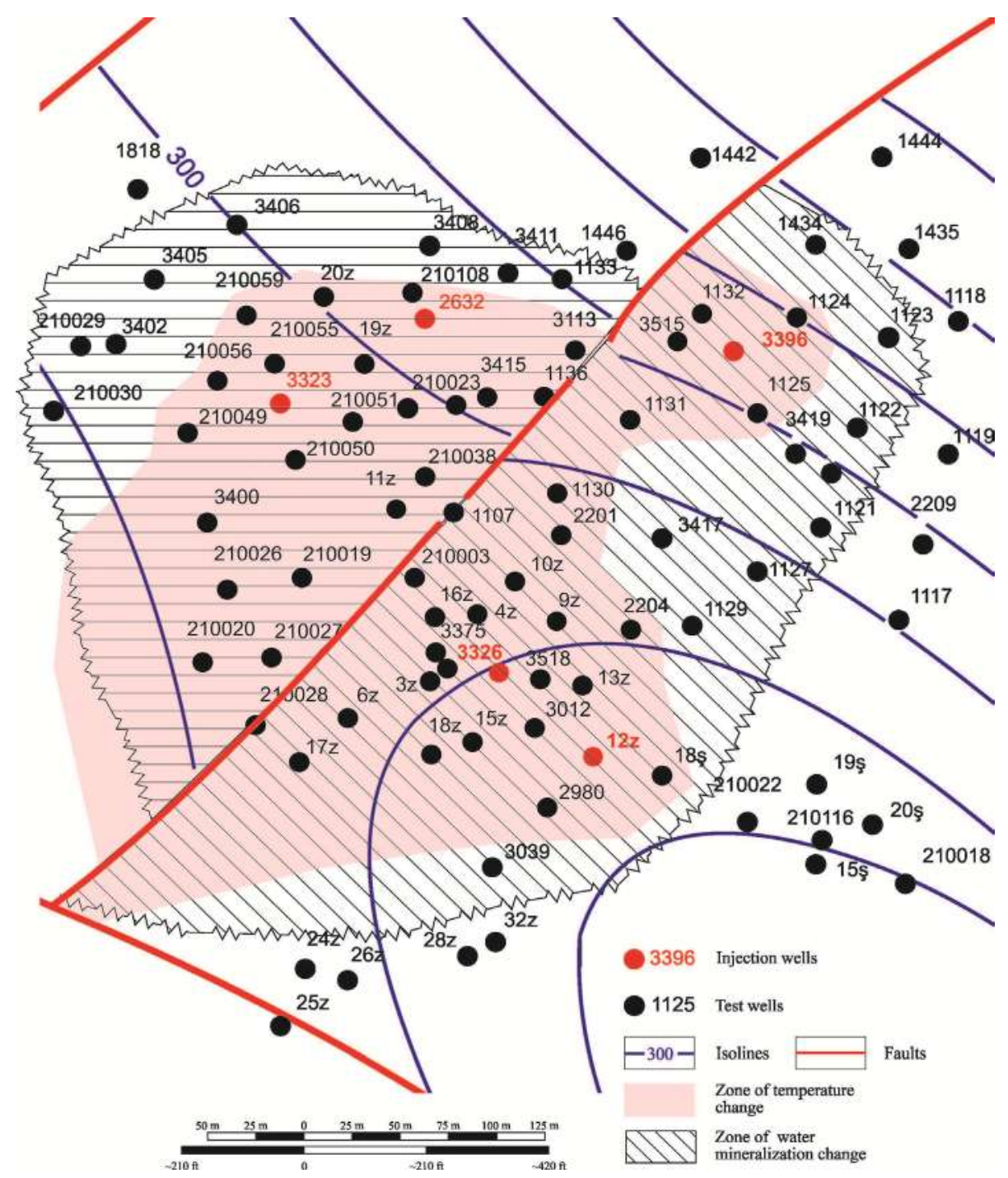

Figure 3. Map of heat distribution as a result of in-situ combustion in Khorasany area of Balakhany-Sabunchi-Ramany field.

Рисунок 3. Карта распределения тепла в результате внутрипластового горения в месторождении Балаханы-Сабунчи-Раманы (площадь Хорасаны).

Table 2. Physical-chemical characteristics of formation water of horizon $\mathrm{PK}_{u}$ at Balakhany-Sabunchi-Ramany field.

Таблица 2. Физико-химические показатели пластовой воды на залежах горизонта $\mathrm{PK}_{u}$ в месторождении Балаханы-СабунчиРаманы.

\begin{tabular}{|c|c|c|c|c|c|c|c|}
\hline \multirow{2}{*}{$\begin{array}{c}\text { Well No. } 3375 \\
\text { Measurement date }\end{array}$} & \multicolumn{7}{|c|}{ Equivalent values } \\
\hline & $\mathrm{Cl}$ & $\mathrm{SO}_{4}$ & $\mathrm{HCO}_{3}$ & $\mathrm{Ca}$ & $\mathrm{Mg}$ & $\mathrm{Na}+\mathrm{K}$ & $\sum_{a+k}$ \\
\hline & \multicolumn{7}{|c|}{ Before the treatment } \\
\hline 24.06.1971 & 0.0252 & 0.0001 & 0.0074 & 0.0002 & 0.0017 & 0.0305 & 0.0651 \\
\hline 28.07.1971 & 0.0235 & 0.0002 & 0.0067 & 0.0006 & 0.0012 & 0.0284 & 0.0606 \\
\hline 22.12 .1971 & 0.0235 & 0.0001 & 0.0066 & 0.0005 & 0.0016 & 0.0281 & 0.0604 \\
\hline 19.03 .1972 & 0.0275 & 0.0001 & 0.0072 & 0.0006 & 0.0013 & 0.0328 & 0.0695 \\
\hline 17.06 .1972 & 0.032 & 0.0003 & 0.0054 & 0.0006 & 0.0017 & 0.0354 & 0.0754 \\
\hline 03.09.1972 & 0.028 & 0.0002 & 0.0068 & 0.0001 & 0.0022 & 0.0327 & 0.07 \\
\hline \multirow[t]{2}{*}{18.01 .1973} & 0.0255 & 0.0004 & 0.0069 & 0.0006 & 0.0016 & 0.0306 & 0.0656 \\
\hline & \multicolumn{7}{|c|}{ After the treatment } \\
\hline 09.04 .1973 & 0.1004 & 0.0086 & 0.0059 & 0.0154 & - & 0.0995 & 0.2298 \\
\hline 26.06 .1973 & 0.087 & - & 0.0062 & 0.0012 & 0.0039 & 0.0881 & 0.1864 \\
\hline 07.09 .1973 & 0.029 & - & 0.0069 & 0.0002 & 0.0019 & 0.0338 & 0.0718 \\
\hline 09.02 .1974 & 0.0265 & 0.0001 & 0.0019 & 0.0004 & 0.0014 & 0.0314 & 0.0617 \\
\hline 19.05 .1974 & 0.0245 & - & 0.0068 & 0.0004 & 0.0017 & 0.0292 & 0.0626 \\
\hline 09.08 .1974 & 0.026 & 0.0006 & 0.0063 & 0.0001 & 0.0023 & 0.0315 & 0.0668 \\
\hline 14.12 .1974 & 0.0275 & 0.0001 & 0.0075 & 0.0002 & 0.0021 & 0.0327 & 0.0701 \\
\hline
\end{tabular}

Багиров Б. А., Гаджиев А. М. Control of movement of heat front during oil reservoir thermal treatment // Известия УГГУ. 2018.21 Вып. 4(52). C. 18-25. DOI 10.21440/2307-2091-2018-4-18-25 


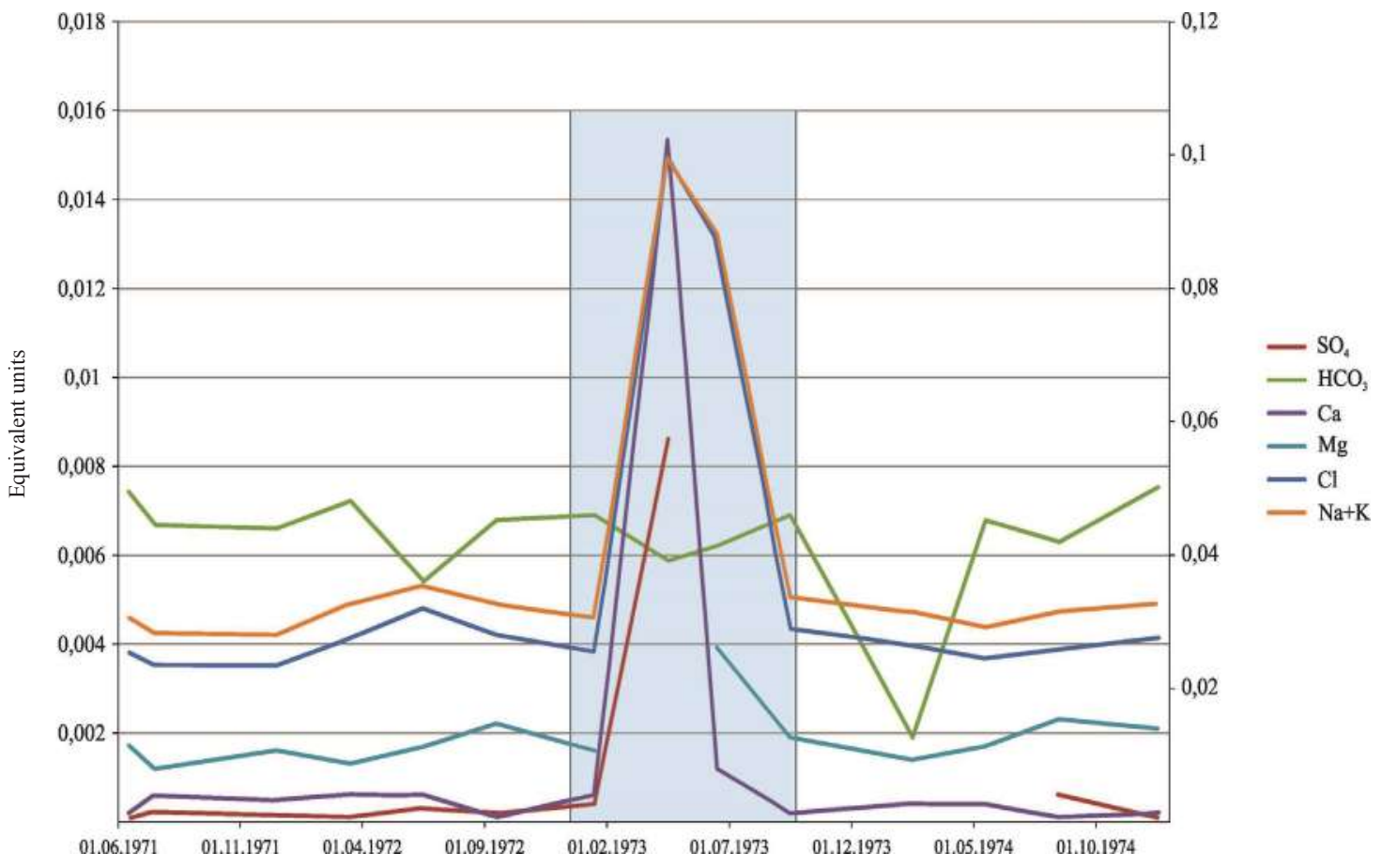

Figure 4. Change of physical-chemical characteristics of formation water in time (well No. 3375).

Рисунок 4. Изменение физико-химических показателей пластовой воды с течением времени (скважина 3375 ).

Table 3. Physical-chemical characteristics of formation water of horizon KCu at Pirallakhi field.

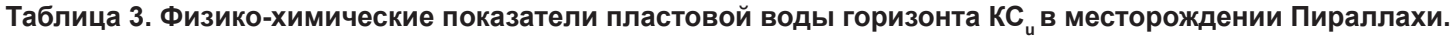

\begin{tabular}{|c|c|c|c|c|c|c|}
\hline \multirow{2}{*}{$\begin{array}{c}\text { Well No. } 633 \\
\text { Measurement date }\end{array}$} & \multicolumn{6}{|c|}{ Equivalent values } \\
\hline & $\mathrm{Cl}$ & $\mathrm{SO}_{4}$ & $\mathrm{HCO}_{3}$ & $\mathrm{Ca}$ & $\mathrm{Mg}$ & $\mathrm{Na}+\mathrm{K}$ \\
\hline & \multicolumn{6}{|c|}{ Before the treatment } \\
\hline 24.01.1978 & 0.1550 & - & 0.0017 & 0.0071 & 0.0050 & 0.1446 \\
\hline 21.02 .1979 & 0.1430 & 0.0009 & 0.0012 & 0.0107 & 0.0076 & 0.1268 \\
\hline 30.10 .1979 & 0.1100 & 0.0013 & 0.0019 & 0.0067 & 0.0063 & 0.1002 \\
\hline 11.01 .1980 & 0.1515 & 0.0007 & 0.0010 & 0.0108 & 0.0066 & 0.1358 \\
\hline 20.03.1980 & 0.1725 & 0.0009 & 0.0008 & 0.0132 & 0.0071 & 0.1539 \\
\hline \multirow[t]{2}{*}{ 23.10.1980 } & 0.1290 & 0.0023 & 0.0008 & 0.0094 & 0.0073 & 0.1154 \\
\hline & \multicolumn{6}{|c|}{ After the treatment } \\
\hline 17.02 .1981 & 0.2000 & 0.0001 & 0.0007 & 0.0112 & 0.0020 & 0.1876 \\
\hline 25.02.1981 & 0.2120 & 0.0001 & 0.0004 & 0.0150 & 0.0077 & 0.1898 \\
\hline 27.03 .1981 & 0.2085 & 0.0001 & 0.0004 & 0.0139 & 0.0104 & 0.1847 \\
\hline 11.05 .1981 & 0.1360 & 0.0004 & 0.0017 & 0.0084 & 0.0061 & 0.1236 \\
\hline 20.05 .1981 & 0.1610 & 0.0014 & 0.0012 & 0.0162 & 0.0046 & 0.1428 \\
\hline 07.08 .1981 & 0.1405 & 0.0015 & 0.0012 & 0.0134 & 0.0028 & 0.1270 \\
\hline 18.12 .1981 & 0.0165 & 0.0053 & 0.0004 & 0.0016 & 0.0052 & 0.0154 \\
\hline 26.01 .1982 & 0.0720 & 0.0012 & 0.0032 & 0.0010 & 0.0053 & 0.0664 \\
\hline 15.03 .1983 & 0.0745 & 0.0010 & 0.0038 & 0.0032 & 0.0046 & 0.0745 \\
\hline 31.05 .1983 & 0.1025 & - & 0.0042 & 0.0032 & 0.0036 & 0.0999 \\
\hline 26.03.1984 & 0.0965 & - & 0.0039 & 0.0014 & 0.0029 & 0.0921 \\
\hline 19.06 .1984 & 0.0800 & - & 0.0041 & 0.0018 & 0.0052 & 0.0771 \\
\hline 08.07.1984 & 0.0845 & 0.0004 & 0.0029 & 0.0052 & 0.003 & 0.0796 \\
\hline 23.10.1984 & 0.0865 & - & 0.0036 & 0.0031 & 0.0039 & 0.0831 \\
\hline 15.11 .1984 & 0.0870 & - & 0.0043 & 0.0037 & 0.0048 & 0.0828 \\
\hline 12.12 .1984 & 0.0610 & 0.0010 & 0.0039 & 0.0034 & 0.0035 & 0.0590 \\
\hline
\end{tabular}

22 Багиров Б. А., Гаджиев А. М. Control of movement of heat front during oil reservoir thermal treatment // Известия УГГУ. 2018. Вып. 4(52). C. 18-25. DOI 10.21440/2307-2091-2018-4-18-25 


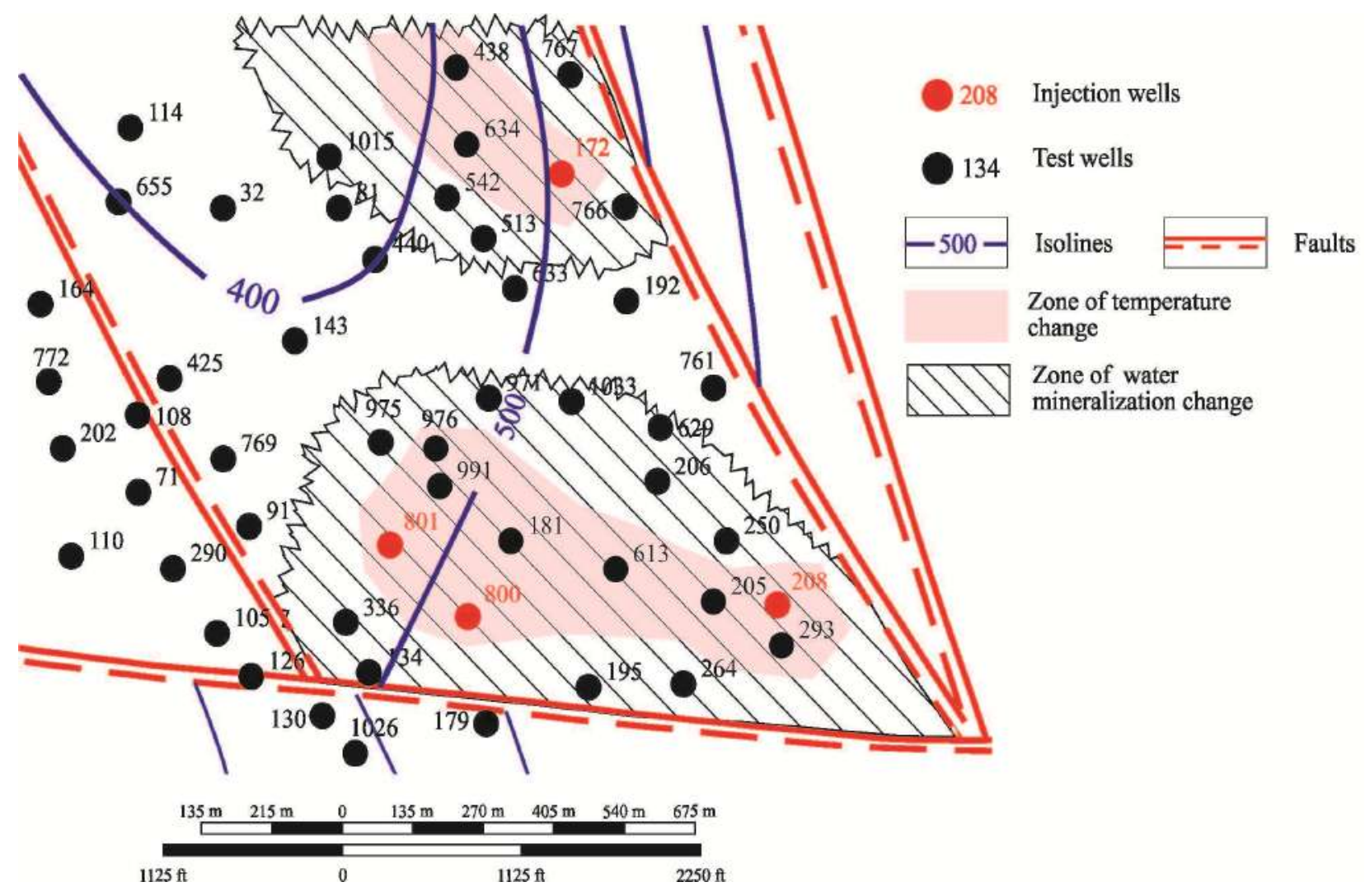

Figure 5. Map of heat distribution as a result of in-situ combustion in horizon $\mathrm{KS}_{\mu}$ of Pirallakhi field.

Рисунок 5. Карта распределения тепла в результате внутрипластового горения в залежах горизонта $\mathrm{KS}_{\mathrm{u}}$ месторождения Пираллахи.

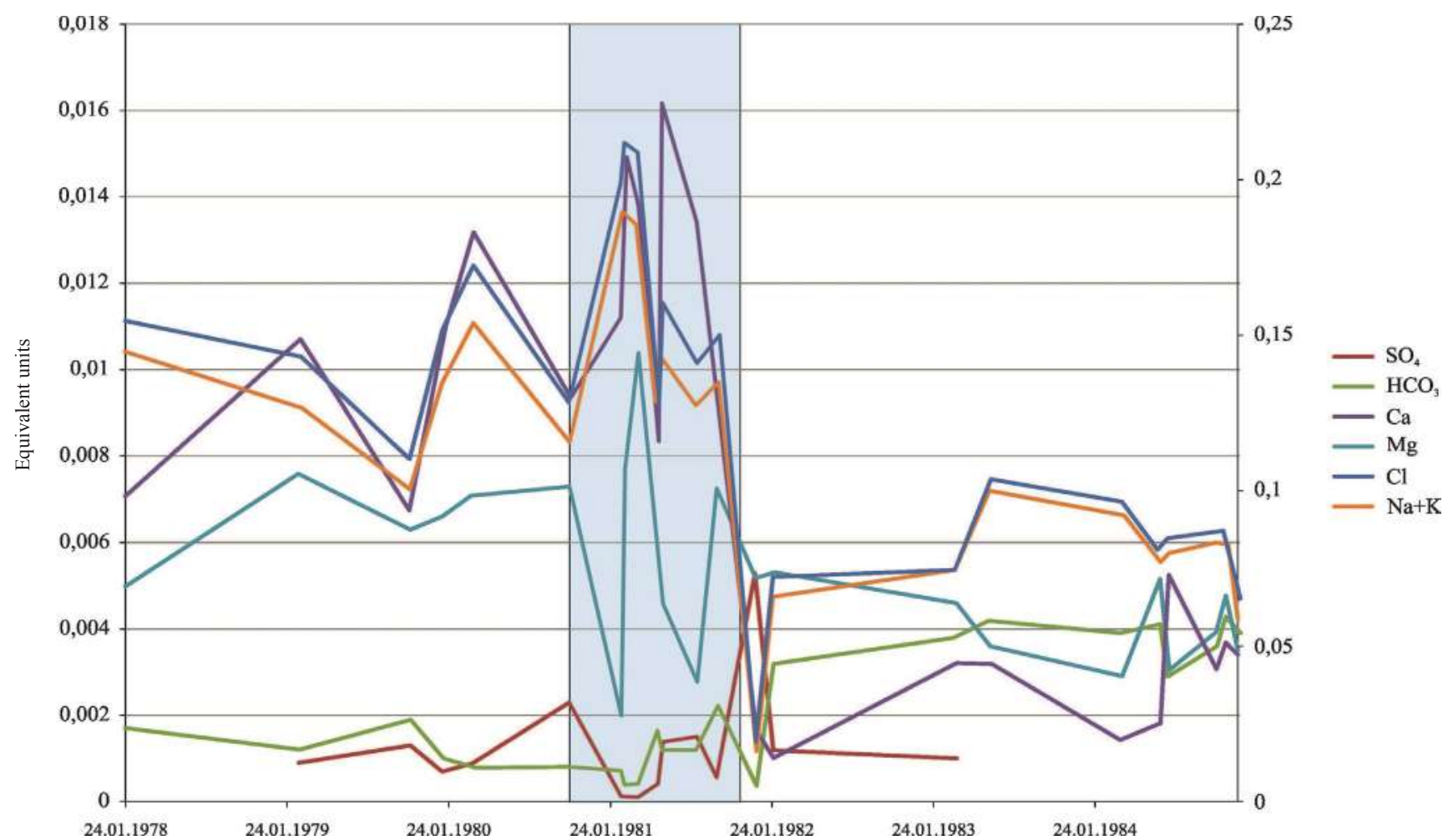

Figure 6. Change of physical-chemical characteristics of formation water in time (well No. 633).

Рисунок 6. Изменение физико-химических показателей пластовой воды с течением времени (скважина 633). 
2. Horizon II KS of the Pirallakhi field. Horizon $\mathrm{KS}_{u}$ of the Pirallakhi field is in development over 70 years. This horizon is quite heterogeneous and compartmentalized, which lead to different level of recovery in different blocks. Accumulation of significant remaining recoverable reserves of highly viscous oil in come blocks required design and application of in-situ combustion method. This method was applied in a number of wells: well 208 - 1974; wells 800 and 801 - 1976; well 172 - 1981; well 843 - 1982 (Fig. 5).

During the period of formation treatment, alongside with other geological-engineering measures hydrochemical studies were carried out. It should be noted that vast volume of data had been accumulated for this target, and increased content of $\mathrm{Na}+$ $\mathrm{K}$ and $\mathrm{Cl}$ ions in formation water was registered. Results of analyses for a number of wells are presented in Table 3, Fig. 6.

Period of thermal stimulation is shown in grey color.

As follows from Fig. 3, 4, 6, affected zones established just by data of thermal studies cover only part of areas, which is related to natural physical tendency of heat to move to elevated parts of the structure. Chemical-structural changes in mineralization of water encompass much greater area, giving better indication of coverage with thermal treatment.

Thermal treatment in a form of hot water injection was not used in the Azerbaijan fields. Nevertheless, one can assume that on injection of hot water mineralization of formation water will change depending on the ion-salt composition of injected water.

Conclusions

1. For the improvement of mobility of highly-viscous oils in reservoirs temperature within the development targets has to be increased.

2. In the process of thermal treatment, in any modification, specific variations in chemical composition of formation water are observed.

3. This effect is in favor of inclusion of water sampling and hydrochemical analysis data into monitoring process of formations thermal treatment.

\section{REFERENCES}

1. Bagirov B. A. 2011, Neftegazopromyslovayya geologiya [Oil-field geology]. Baku, 311 p.

2. Ruzin L. M., Morozyuk O. A. 2014, Metody povysheniya nefteotdachi plastov (teoriya i praktika) [Methods of increasing petroleum oil reservoirs (theory and practice)]. Ukhta, $127 \mathrm{p}$.

3. Horn G. M. 2010, Coal, Oil, and Natural Gas (Energy today). N. Y., 48 p.

4. Bagirov B. A., Salmanov A. M., Gasanaliev M. G. 1998, Determining the quality of oil reserves. Geologiya nefti $i$ gaza [Oil and Gas Geology], no. 1, pp. 22-25. (In Russ.)

5. Baibakov N. K., Garushev A. R. 1988, Teplovyye metody razrabotki neftyanykh mestorozhdeniy [Thermal methods of oil fields development]. Moscow, $343 p$.

6. Qiuyue Song, Zhangxin Chen, S. M. Farouq Ali. 2015, Steam Injection Schemes for Bitumen Recovery from the Grosmont Carbonate Deposits. SPE Canada Heavy Oil Technical Conference, Calgary Alberta Canada, Society of Petroleum Engineers. 37 p. https://doi.org/10.2118/174463-MS 7. Ezeuko C. C., Wang J., Kallos M. S., Gates I. D. 2015, Towards the Development of Bitumen Carbonates: An Integrated Analysis of Grosmont Steam Pilots. Oil \& Gas Science and Technology, vol. 70, no. 6, pp. 983-1005. https://doi.org/10.2516/ogst/2013111

8. Nesterov I., Shapiro A., Stenby E. H. 2013, Numerical analysis of a one-dimensional multicomponent model of the in-situ combustion process. Journal of Petroleum Science and Engineering, vol. 106, pp. 46-61. https://doi.org/10.1016/j.petrol.2013.03.022

9. Youtsos M. S. K., Mastorakos E., Cant R. S. 2013, Numerical simulation of thermal and reaction fronts for oil shale upgrading. Chemical Engineering Science, vol. 94, pp. 200-213. https://doi.org/10.1016/j.ces.2013.02.040

10. García Hugo, Niz Velásquez Eider, Trujillo Martha 2016, Optimization of management of possible manufacturing problems in the progress of the implementation of the project of In-situ combustion at the deposit of Chichimen, Colombia, Georesources, vol. 18, no. 4-1, pp. 289-298. http:// dx.doi.org/10.18599/grs.18.4.6

11. Amelin I. D. 1980, Vnutriplastovoye goreniye [In-situ combustion]. Moscow, 230 p.

12. Surguchev M. L. 1985, Vtorichnyye i tretichnyye metody uvelicheniya nefteotdachi plastov [Secondary and tertiary formation stimulation methods]. Moscow, $308 \mathrm{p}$.

13. Gutiérrez D., Moore R. G., Ursenbach M. G., Sudarshan A. M. 2012, The ABCs of In-Situ-Combustion Simulations: From Laboratory Experiments to Field Scale. Journal of Canadian Petroleum Technology, vol. 51, issue 4, pp. 256-267. https://doi.org/10.2118/148754-PA

14. Isakov D. R., Nurgaliev D. K., Shaposhnikov D. A., Chernova O. S. 2014, Features of mathematical modeling of in-situ combustion for production of high-viscosity crude oil and natural bitumens. Khimiya i tekhnologiya topliv i masel [Chemistry and Technology of Fuels and Oils], no. 6(586), pp. 81-83. https://doi.org/10.1007/s10553-015-0561-5

15. Shojaiepour M., Kharrat R., Shojaiepour M., Hashemi A. 2014, Experimental and simulation study of in-situ combustion process in carbonate fractured porous media. Journal of the Japan Petroleum Institute, vol. 57, no. 5, pp. 208-215. https://doi.org/10.1627/jpi.57.208 


\title{
Контроль за продвижением теплового потока в процессе разработки нестяных месторожлений с применением термической обработки
}

\author{
Багир Али оглы БАГИРОВ ${ }^{1, ~ *,}$ \\ Агарза Месуд оглы ГАДЖИЕВ ${ }^{2, *}$ \\ ${ }^{1}$ Азербайджанский государственный университет нефти и промышленности, Баку, Азербайджан \\ 2НИПИ «Нефтегаз», SOCAR, Баку, Азербайджан
}

\begin{abstract}
Актуаньность. Аяя увеличения нестеотдачи пластов в процессе разработки залежей применяются тепловые методы (закачка в пласт пара и горячей воды, внутрипластовое горение). Эффективное применение этих методов требует надежного контроля проводимых процессов. С этой целью обычно проводятся соответствуюшие замеры в скважинах, результаты которых отражаются на картах изотерм. Сопоставление таких карт, составленных мля различных периодов разработки залежей, позволяет получать инсормацию о направлении и скорости продвижения теплоносителя по пласту. В итоге выдвигается концепция о регулировании (если это необходимо) проводимых процессов.

Цель и задачи исследования. Проводимые нами геолого-промысловые исследования по месторождениям Азербайджана показывают, что дяя более намежного контроля за тепловоздействием целесообразно использовать данные о гидрохимии пласта. Так, при внедрении теплоносителя не только повышается температура пласта и тем самым снижается вязкость и плотность пластовых нестей, но и изменяются сизико-химические характеристики пластовых вод. Следует отметить и то, что в процессе термовоздействия наряду с пластовыми флюидами подвергается изменениям и порода этого пласта. В итоге тепло, продвигаюшееся от возбужАаюшей скважины к скважинам реагируюшим, представляет собой весьма сложную термодинамическую систему. К тому же процесс изменения гидрохимии пласта всегАа опережает подобные процессы в нестях и породах залежи. Именно этим обстоятельством обосновывается необходимость вкиючения в комплекс исследований по контролю за тепловоздействием инсоормации о гицрохимии пласта.

Вывод. Опираясь на материалы разработки ряда месторождений Азербайджана, авторы выявили механизм изменчивости теплового режима залежей. В частности, было установлено, что при закачке в пласт пара, представляюшего собой, по сушеству, дистимированную воду, соленость вод залежей уменьшается; при внутрипластовом горении за счет резкого повышения температуры пласта повышается и химическая активность вод. Это, как правияо, приводит к изменению химизма вод (содержание $\mathrm{Na}+\mathrm{K}$ и Сl повышается). Концепция, выдвинутая в данной статье, подтвержАается геолого-промысловой информацией и имюстрируется соответствуюшими картами и таблицами.
\end{abstract}

Киючевые слова: резервуар, нестеотдача, термическое воздействие, температура, паровоздействие, внутрипластовое горение, минераиизация воды.

\section{ЛИТЕРАТУРА}

1. Багиров Б. А. Нефтегазопромысловая геология. Баку: Изд. АГНА, 2011. 311 с.

2. Рузин Л. М., Морозюк О. А. Методы повышения нефтеотдачи пластов (теория и практика). Ухта: УГТУ, 2014. 127 с.

3. Horn G. M. Coal, Oil, and Natural Gas (Energy today). N. Y., 2010. 48 p.

4. Багиров Б. А., Салманов А. М., Гасаналиев М. Г. Об определении качества запасов нефти // Геология нефти и газа. 1998. № 1, с. $22-25$.

5. Байбаков Н. К., Гарушев А. Р. Тепловые методы разработки нефтяных месторождений. М.: Недра, 1988. 343 с.

6. Song Q., Chen Zh., Farouq Ali S. M. Steam Injection Schemes for Bitumen Recovery from the Grosmont Carbonate Deposits / SPE Canada Heavy Oil Technical Conference, Calgary Alberta Canada, Society of Petroleum Engineers. 2015. 37 p. https://doi.org/10.2118/174463-MS

7. Ezeuko C. C., Wang J., Kallos M. S., Gates I. D. Towards the Development of Bitumen Carbonates: An Integrated Analysis of Grosmont Steam Pilots // Oil \& Gas Science and Technology. 2015. Vol. 70, № 6. P. 983-1005. https://doi.org/10.2516/ogst/2013111

8. Nesterov I., Shapiro A., Stenby E. H. Numerical analysis of a one-dimensional multicomponent model of the in-situ combustion process // Journal of Petroleum Science and Engineering. 2013. Vol. 106, June. P. 46-61. https://doi.org/10.1016/j.petrol.2013.03.022

9. Youtsos M. S. K., Mastorakos E., Cant R. S. Numerical simulation of thermal and reaction fronts for oil shale upgrading // Chemical Engineering Science. 2013. Vol. 94, 3 May. P. 200-213. https://doi.org/10.1016/j.ces.2013.02.040

10. García H., Niz Velásquez E., Trujillo M. Anticipating Operational Issues for the Field Pilot Test of Air Injection in Chichimene, Colombia // Georesources. 2016. Vol. 18. № 4-1. P. 289-298. http://dx.doi.org/10.18599/grs.18.4.6

11. Амелин И. Д. Внутрипластовое горение. М.: Недра, 1980. 230 с.

12. Сургучев М. Л. Вторичные и третичные методы увеличения нефтеотдачи пластов. М.: Недра, 1985. 308 с.

13. Gutiérrez D., Moore R. G., Ursenbach M. G., Sudarshan A. M. The ABCs of In-Situ-Combustion Simulations: From Laboratory Experiments to Field Scale // Journal of Canadian Petroleum Technology. 2012. Vol. 51, issue 4. P. 256-267. https://doi.org/10.2118/148754-PA

14. Исаков Д. Р., Нургалиев Д. К., Шапошников Д. А., Чернова О. С. Особенности математического моделирования метода внутрипластового горения при добыче высоковязких нефтей и природных битумов // Химия и технология топлив и масел. 2014. № 6(586). C. 81-83. URL: http://www.nitu.ru/xttm/2014_6.pdf

15. Shojaiepour M., Kharrat R., Shojaiepour M., Hashemi A. Experimental and simulation study of in-situ combustion process in carbonate fractured porous media // Journal of the Japan Petroleum Institute. 2014. Vol. 57, № 5. P. 208-215. https://doi.org/10.1627/jpi.57.208

b.bagirov.36@mail.ru

"*agarza.haciyev@gmail.com 